\title{
PENGARUH RETURN ON ASSET, NET PROFIT MARGIN DAN EARNING PER SHARE TERHADAP HARGA SAHAM PADA PERUSAHAAN YANG TERCANTUM DALAM INDEKS LQ45
}

\author{
Agus Haryanto 1 \\ agusharyanto@gmail.com \\ Jack H. Syauta ${ }^{2}$ \\ jacksyauta@ymail.com \\ 1-2 Fakultas Ekonomi dan Bisnis Universitas Cenderawasih
}

\begin{abstract}
Abstraksi:
Penelitian ini bertujuan untuk menguji dan menganalisis pengaruh Return On Asset, Net Profit Margin dan Earning Per Share secara parsial dan simultan terhadap harga saham pada perusahaan yang tercantum dalam Indeks LQ45 periode 2016-2019.Pendekatan Penelitian dengan pendekatan kuantitatif. Sampel dalam penelitian ini berjumlah 13. Sumber data yang digunakan adalah data sekunder dengan teknik pengumpulan data yaitu Studi Kepustakaan dan Teknik Dokumentasi. Kemudian di analisis menggunakan analisis regresi linier berganda dengan bantuan software SPSS 25.Hasil penelitian menunjukkan bahwa secara parsial Return On Asset dan Earning Per Share berpengaruh signifikan terhadap Harga Saham. Sedangkan Net Profit Margin tidak berpengaruh signifikan terhadap harga saham. Secara simultan Return On Asset, Net Profit Margin dan Earning Per Share berpengaruh signifikan terhadap Harga Saham. Pengaruh variabel Return On Asset, Net Profit Margin dan Earning Per Share secara simultan terhadap Harga Saham sebesar $61,7 \%$..
\end{abstract}

Kata Kunci : Return on Asset, Net Profit Margin, Earning per Share, Harga Saham

\section{PENDAHULUAN}

\section{A. Latar Belakang}

Pada era globalisasi seperti saat ini, dimana perkembangan teknologi dan informasi yang cepat, persaingan dalam dunia usaha menjadi begitu ketat. Satu-satunya jalan untuk tetap bertahan dan bersaing serta mempertahankan eksistensinya di dunia usaha yakni dengan terus tumbuh dan berkembang, salah satu yang dibutuhkan oleh perusahaan untuk terus tumbuh dan berkembang adalah modal. Ada berbagai macam sumber permodalan yang dapat diperoleh oleh seorang pengusaha untuk dapat tumbuh dan berkembang, antara lain; berasal dari modal sendiri, pinjaman dari pihak lain, seperti bank, atau menghimpun dana dari pihak ketiga, seperti lewat penerbitan saham (stock) perusahaan untuk di jual kepada publik atau pihak ketiga melalui Pasar Modal. Peranan pasar modal sekarang ini dirasakan sangat penting berkaitan dengan fungsi dari pasar modal itu sendiri yaitu mempertemukan pihak yang membutuhkan dana dengan pihak yang ingin menanamkan modalnya pada pasar modal. Salah satu unsur dalam investasi di pasar modal adalah harga saham. Harga saham mencerminkan juga nilai dari suatu perusahaan. Harga saham selalu mengalami fluktuasi sehingga dibutuhkan pendekatan untuk memprediksi harga saham dan dalam pengambilan keputusan investasi.

Secara umum masyarakat pemodal (investor) yang akan melakukan investasi, terlebih dahulu melakukan pengamatan dan penilaian terhadap perusahaan yang akan dipilih dengan terus memantau laporan keuangan perusahaan-perusahaan tersebut terutama perusahaan yang sudah go public. Berdasarkan laporan keuangan tersebut dapat diketahui kinerja perusahaan dalam menjalankan perubahan dalam bidang politik, ekonomi moneter, Undang-undang atau peraturan maupun perubahan yang terjadi dalam industri dan perusahaan yang mengeluarkan saham itu sendiri. Sehingga investor dalam melakukan pembelian saham memerlukan pemikiran berdasarkan data-data dari perusahaan yang bersangkutan.

Penentuan harga saham salah satunya didasarkan pada kinerja perusahaan. Kinerja perusahaan dapat dilihat dari laporan keuangan yang dirilis oleh perusahaan tersebut. Laporan keuangan menunjukkan informasi mengenai keadaan suatu perusahaan yang bisa dijadikan sumber informasi bagi pengambilan keputusan. Sebuah perusahaan terbuka maupun perseorangan memiliki tujuan untuk meningkatkan kesejahteraan para pemilik perusahaan maupun investornya. Tujuan 
tersebut dapat dicapai dengan memperbesar laba yang diperoleh perusahaan tiap tahunnya. Untuk sebuah perusahaan terbuka, tujuan memaksimalkan laba yang besar tersebut dimaksudkan agar dapat meningkatkan kesejahteraan para pemegang sahamnya dengan cara membagikan deviden setiap tahunnya. Perusahaan mempunyai berbagai macam usaha dalam menarik jumlah investor dan meningkatkan harga sahamnya, salah satunya yaitu dengan cara mengevaluasi faktorfaktor yang sangat berpengaruh terhadap peningkatan harga saham suatu perusahaan.

Return On Asset mengukur kemampuan perusahaan dalam memanfaatkan aset untuk memperoleh laba. Ratio ini mengukur tingkat kembalian investasi yang telah dilakukan oleh perusahaan dengan menggunakan seluruh aset yang dimilikinya. Ratio ini dapat diperbandingkan dengan tingkat bunga bank yang berlaku. Menurut Dwi (2019), NPM adalah semakin besar rasio, berarti semakin bagus perusahaan dalam menghasilkan laba. Semakin tinggi NPM maka akan mempengaruhi tingkat kinerja perusahaan, sehingga akan membuat perusahaan semakin baik dan dapat menyebabkan harga saham meningkat, disinilah akan menimbulkan kepercayaan investor untuk menanamkan modal pada perusahaan tersebut. Menurut Dwi (2019) Earning Per Share (EPS) adalah jumlah laba yang menjadi hak untuk setiap pemegang satu lembar saham biasa. EPS hanya dihitung untuk saham biasa. Tergantung dari struktur modal perusahaan, perhitungan EPS dapat sederhana atau kompleks. Menurut Brigham dan Houtson di dalam jurnal Prayogi (2020) Harga saham sangat dipengaruhi oleh supply and demand yang terjadi di pasar modal. Harga saham merupakan hasil dari akumulasi faktor-faktor yang memengaruhi perubahan harga saham tersebut.

Penelitian yang pernah dilakukan oleh Rosdian dan Ventje (2016) menyimpulkan bahwa Return On Asset, Net Profit Margin dan Earning Per Share berpengaruh signifikan terhadap harga saham, secara simultan ataupun parsial. Selanjutnya penelitian yang dilakukan oleh Gerald, Ventje dan Sonny (2017) menunjukkan bahwa ROA dan ROE tidak memiliki pengaruh terhadap harga saham. NPM berpengaruh negatif terhadap harga saham. EPS berpengaruh positif terhadap harga saham. Sedangkan penelitian Putri dan Budhi (2019) menunjukkan bahwa variabel Return On Asset dan Earning Per Share tidak berpengaruh terhadap harga saham, Sedangkan Return On Equity dan Net Profit Margin berpengaruh terhadap harga saham. Dari ketiga penelitian terdahulu terdapat inkonsistensi hasil dari penelitian yang dilakukan oleh Rosdian dan Ventje (2016), Gerald, Ventje dan Sonny (2017) dan Putri dan Budhi (2019). Berdasarkan uraian diatas, penulis terdorong untuk melakukan penelitian dengan judul Pengaruh Return On Asset (ROA), Net Profit Margin (NPM) dan Earning Per Share (NPM) Terhadap Harga Saham Perusahaan Yang Terdaftar Dalam Indeks LQ45 Periode 2016-2019.

\section{B. Perumusan Masalah}

Berdasarkan latar belakang yang dikemukakan di atas, maka dirumuskan permasalahan penelitian sebagai berikut:

1. Apakah return on asset berpengaruh signifikan terhadap harga saham pada perusahaan yang tercantum dalam indeks LQ45 periode 2016-2019?

2. Apakah Net Profit Margin berpengaruh signifikan terhadap harga saham pada perusahaan yang tercantum dalam Indeks LQ45 periode 2016-2019?

3. Apakah Earning Per Share berpengaruh signifikan terhadap harga saham pada perusahaan yang tercantum dalam Indeks LQ45 periode 2016-2019?

4. Apakah Return On Asset, Net Profit Margin dan Earning Per Share secara simultan berpengaruh signifikan terhadap harga saham pada perusahaan yang tercantum dalam Indeks LQ45 periode 2016-2019?

\section{Tujuan Penelitian}

Adapun tujuan penulisan yang akan dikemukakan adalah :

1. Menguji dan menganalisis pengaruh Return On Asset terhadap harga saham pada perusahaan yang tercantum dalam Indeks LQ45 periode 2016-2019.

2. Menguji dan menganalisis pengaruh Net Profit Margin terhadap harga saham pada perusahaan yang tercantum dalam Indeks LQ45 periode 2016-2019.

3. Menguji dan menganalisis pengaruh Earning Per Share terhadap harga saham pada perusahaan yang tercantum dalam Indeks LQ45 periode 2016-2019. 
4. Menguji dan menganalisis Return On Asset, Net Profit Margin dan Earning Per Share secara simultan terhadap harga saham pada perusahaan yang tercantum dalam Indeks LQ45 periode 2016-2019.

\section{LANDASAN TEORI}

\section{A. Kajian Teori}

\section{Laporan Keuangan}

Pengertian laporan keuangan menurut Standar Akuntansi Keuangan (SAK) di dalam buku Wiratna (2019) laporan keuangan merupakan bagian dari proses pelaporan keuangan. Laporan keuangan yang lengkap biasanya meliputi neraca, laporan laba rugi, laporan perubahan posisi keuangan (yang dapat disajikan dalam berbagai cara misalnya sebagai laporan arus kas, atau laporan arus dana), catatan dan laporan lain serta materi penjelasan yang merupakan bagian integral dari laporan keuangan. Secara umum laporan keuangan adalah catatan informasi keuangan suatu perusahaan pada suatu periode akuntansi yang dapat digunakan untuk menggambarkan kinerja perusahaan tersebut.

\section{Tujuan Laporan Keuangan}

Tujuan laporan keuangan menurut Dwi (2019) Laporan keuangan disusun dengan tujuan untuk menyediakan informasi yang menyangkut posisi laporan keuangan, kinerja dan posisi keuangan suatu perusahaan yang bermanfaat bagi sejumlah besar pemakai dalam pengambilan keputusan ekonomi. Informasi mengenai posisi keuangan, kinerja, dan perubahan posisi keuangan sangat diperlukan untuk dapat melakukan evaluasi atas kemampuan perusahaan dalam menghasilkan kas (dan setara kas) dan waktu serta kepastian dari hasil tersebut. Laporan keuangan (finacial statements) merupakan produk akhir dari serangkaian proses pencacatan dan pengikhtisaran data transaksi bisnis. Komponen laporan keuangan meliputi laporan laba-rugi, laporan ekuitas pemilik, neraca, laporan arus kas dan catatan atas laporan keuangan. (Hery, 2015).

\section{Karakteristik laporan Keuangan}

Karakteristik kualitatif laporan keuangan menurut Dwi (2019) merupakan ciri khas yang membuat informasi dalam laporan keuangan tersebut berguna bagi para pemakai dalam pengambilan keputusan ekonomi. Karakteristik kualitatif laporan keuangan ini meliputi:

a. Dapat dipahami, Kualitas penting informasi yang ditampung dalam laporan keuangan adalah kemudahannya untuk segera dapat dipahami oleh para pemakai. Dalam hal ini, para pemakai diasumsikan memiliki pengetahuan yang memadai tentang aktivitas ekonomi dan bisnis, akuntansi serta kemauan untuk mempelajari informasi dengan ketekunan yang wajar. Namun demikian, sulitnya memahami informasi yang kompleks jangan di jadikan alasan untuk tidak memasukkan informasi tersebut dalam laporan.

b. Relevan, Agar bermanfaat, informasi harus relevan untuk memenuhi kebutuhan para pemakai dalam proses pengambilan keputusan. Informasi memiliki kualitas relevan apabila informasi tersebut dapat mempengaruhi keputusan ekonomi pemakai dengan membantu mereka mengevaluasi peristiwa masa lalu, masa kini atau masa depan (predictive), menegaskan atau mengoreksi, hasil evaluasi mereka di masa lalu (confirmatory). Relevansi informasi dipengaruhi oleh hakikat dan materialitasnya. Informasi dipandang material apabila kelalaian untuk mencantumkan atau kesalahan dalam mencatat informasi tersebut dapat mempengaruhi keputusan ekonomi pemakai yang di ambil atas dasar laporan keuangan.

c. Keandalan, Agar bermanfaat, informasi juga harus andal (reliable). Informasi mempunyai kualitas andal jika bebas dari pengertian yang menyesatkan, kesalahan material dan dapat diandalkan pemakainya sebagai penyajian yang tulus dan jujur (faithful representation) dari yang seharusnya disajikan atau yang secara wajar diharapkan dapat disajikan. Agar dapat diandalkan, informasi yang disajikan dalam laporan keuangan harus lengkap dalam batasan materialitas dan biaya (kelengkapan). Kesengajaan untuk tidak mengungkapkan (omission) dapat mengakibatkan informasi informasi menjadi tidak benar dan menyesatkan. 
d. Dapat dibandingkan, Para pemakai laporan keuangan harus dapat membandingkan laporan keuangan perusahaan antar periode untuk mengidentifikasi kecenderungan (trend) posisi keuangan dan kinerja perusahaan Selain itu, pemakai juga harus dapat memperbandingkan laporan keuangan antarperusahaan untuk mengevaluasi posisi keuangan, kinerja serta perubahan posisi keuangan secara relatif.

\section{Jenis Laporan Keuangan}

Laporan keuangan menurut Dwi (2019) yang lengkap biasanya akan meliputi laporan posisi keuangan atau neraca, laporan laba rugi dan laporan komprehensif lainnya, laporan perubahan posisi keuangan, laporan arus kas, catatan dan laporan lain serta materi penjelasan yang merupakan bagian integral dari laporan keuangan, termasuk juga skedul dan informasi tambahan yang berkaitan dengan laporan keuangan.Dua jenis laporan keuangan (utama) yang umumnya dibuat oleh setiap perusahaan adalah laporan posisi keuangan atau neraca dan laporan laba rugi dan penghasilan komprehensif lainnya (dan biasanya dilengkapi dengan laporan perubahan ekuitas), yang masingmasing dapat dijelaskan sebagai berikut:

a. Laporan Posisi Keuangan atau Neraca

Laporan Posisi Keuangan atau Neraca adalah laporan keuangan yang memberikan informasi mengenai posisi keuangan (aset, liabilitas, dan ekuitas) perusahaan pada saat tertentu.

b. Laporan Laba-Rugi dan Penghasilan Komprehensif Lain

Laporan Laba-Rugi dan Penghasilan Komprehensif Lainny adalah laporan keuangan yang memberikan informasi mengenai kemampuan (potensi) perusahaan dalam menghasilkan laba (kinerja) selama periode tertentu.

Meskipun laporan posisi keuangan atau neraca dan laporan laba rugi dan penghasilan komprehensif lainnya merupakan dua dokumen terpisah, akan tetapi keduanya mempunyai hubungan yang sangat erat dan saling terkait, serta merupakan suatu siklus. Antara posisi keuangan atau neraca dan laporan laba rugi dan penghasilan komprehensif lainnya sering dihubungkan dengan satu laporan yang disebut laporan perubahan ekuitas (saldo laba), yang memberikan informasi mengenai perubahan ekuitas (saldo laba) selama periode tertentu.

\section{Analisis Laporan Keuangan}

Analisis laporan keuangan menurut Dwi (2019) secara harfiah, analisis laporan keuangan terdiri atas dua kata, yaitu analisis dan laporan keuangan. Ini berarti juga bahwa analisis laporan keuangan merupakan suatu kegiatan menganalisis laporan keuangan suatu perusahaan. Menurut kamus besar bahasa Indonesia, kata analisis sendiri didefinisikan sebagai berikut, Penguraian suatu pokok atas berbagai bagiannya dan penelaahan bagian itu sendiri serta hubungan antarbagian untuk memperoleh pengertian yang tepat dan pemahaman arti keseluruhan. Menurut pengertian ini, analisis laporan keuangan tidak lain merupakan suatu proses untuk membedah laporan keuangan ke dalam unsur-unsurnya, menalaah masing-masing unsur tersebut, dan menelaah hubungan diantara unsur-unsur tersebut, dengan tujuan untuk memperoleh pengertian dan pemahaman yang baik dan tepat atas laporan keuangan itu sendiri. ini berarti para analis laporan keuangan dituntut mempunyai pengertian yang cukup tentang unsur-unsur yang membentuk laporan keuangan.

\section{Saham}

Saham menurut Ryan (2018) saham adalah sebuah bukti investasi/kepemilikan seseorang dalam usaha perusahaan tersebut. Saham sesuai dengan klasifikasinya terbagi menjadi dua jenis, yaitu saham khusus dan saham biasa. Saham khusus adalah saham yang memiliki hak khusus dalam perusahaan (misalnya: mendapat pembagian keuntungan perusahaan terlebih dahulu dibandingkan pemilik saham lainnya) sedangkan saham biasa adalah saham yang tidak memiliki hak lebih selain hak umum yaitu mendapatkan pembagian keuntungan sesuai dengan jadwal pembagian keuntungan yang akan dirapatkan dalam Rapat Umum Pemegang Saham (RUPS). DI Pasar Modal terdapat dua jenis saham yaitu saham biasa (common stock) dan saham preferen. 


\section{Harga Saham}

Harga saham yang terjadi di pasar modal merupakan harga yang terbentuk dari kekuatan permintaan dan penawaran yang ada di bursa. Oleh karena itu sebelum mengambil keputusan untuk menjual atau membeli saham, investor berkepentingan untuk menilai harga saham untuk menentukan tingkat keuntungan yang diharapkan. Menurut Weygandt (2015) di dalam jurnal Indra, Veny dan Sekar (2018), ada beberapa keistimewaan yang harus dimiliki oleh investor saham biasa adalah sebagai berikut:

a. Hak kontrol: investor mempunyai hak untuk kontrol siapa yang akan memimpin perusahaan.

b. Hak menerima pembagian keuntungan: Investor akan mendapatkan keuntungan yang dihasilkan oleh perusahaan dalam bentuk dividen.

c. Hak preemptif: hak investor untuk mendapatkan presentasi kepemilikan yang sama jika perusahaan mengeluarkan tambahan lembar saham untuk tujuan melindungi hak kontrol dari investor lama dan untuk melindung harga saham dari kemerosotan nilai.

d. Hak untuk mendapatkan residual claim: investor mendapatkan hak pembagaian aset perusahaan saat terjadi likuidasi dalam perusahaan, namun hak ini akan didapatkan oleh investor jika masih terdapat sisa aset perusahaan setelah perusahaan melakukan pelunasan semua kewajiban kepada investor.

\section{Indeks LQ45}

Indeks LQ45 dibuat dan diterbitkan oleh Bursa Efek Indonesia (www.idx.co.id $)$. Indeks ini terdiri dari 45 saham dengan likuiditas (liquid) tinggi yang diseleksi melalui beberapa kriteria pemilihan. Selain penilaian atas likuiditas, seleksi atas saham-saham tersebut juga mempertimbangkan kapitalisasi pasar. Ukuran utama likuiditas transaksi yakni mengacu pada nilai transaksi pada pasar regular. Sesuai dengan perkembangan pasar dan untuk mempertajam kriteria likuiditas, maka sejak bulan Januari 2005 jumlah hari perdagangan dan frekuensi transaksi dimasukkan sebagai ukuran likuiditas.

\section{Return On Asset (ROA)}

Return On Asset menurut Dwi (2019) Return On Asset mengukur kemampuan perusahaan dalam memanfaatkan aset untuk memperoleh laba. Ratio ini mengukur tingkat pengembalian investasi yang telah dilakukan oleh perusahaan dengan menggunakan seluruh dana (aset) yang dimiliki. Rasio ini dapat diperbandingkan dengan tingkat suku bunga bank yang berlaku.

\section{Net Profit Margin}

Net Profit Margin menghitung sejauh mana kemampuan perusahaan menghasilkan keuntungan (profitabilitas) pada tingkat penjualan, asset dan modal saham tertentu. Rasio ini bisa di interpretasikan juga sebagai kemampuan perusahaan menekan biaya-biaya (ukuran efisiensi) di perusahaan pada periode tertentu (Hanafi, 2016). Jadi, besar kecilnya NPM akan menggambarkan bahwa kinerja suatu perusahaan semakin baik atau buruk yang akan berdampak pada pemegang saham apakah akan meningkatkan kepercayaan investor untuk menanamkan modalnya dan memperoleh keuntungan atau bahkan membuat para pemegang saham mendapatkan laba yang yang rendah.

\section{Earning per Share}

Earning Per Share menurut Fahmi (2017) di dalam jurnal Novita dan Argo (2020) EPS adalah rasio yang menjelaskan laba bersih dengan jumlah saham yang beredar dengan memperkirakan seberapa besar perusahaan menghasilkan keuntungan. EPS adalah hak pemegang saham untuk membandingkan laba bersih dengan jumlah saham yang beredar. Selain itu menurut Dwi (2019) Seorang investor membeli dan mempertahankan saham suatu perusahaan dengan harapan akan memperoleh deviden atau capital gain. Laba biasanya menjadi dasar penentuan pembayaran deviden dan kenaikan nilai saham di masa datang. Oleh karena itu, para pemegang saham biasanya tertarik dengan angka EPS yang dilaporkan perusahaan. Pengembalian atau return yang tinggi dari investasinya sehingga investor akan lebih tertarik untuk berinvestasi di perusahaan yang mempunyai EPS yang tinggi, apabila EPS suatu 
perusahaan dinilai tinggi oleh investor, maka hal ini akan menyebabkan harga saham perusahaan tersebut cenderung bergerak naik (Dewi, Adiputra dan Yuniarta , 2015).

\section{Hipotesis}

Berdasarkan model penelitian maka hipotesis dari penelitian ini adalah sebagai berikut.

$\mathrm{H}_{1}$ : Return On Asset berpengaruh signifikan terhadap harga saham perusahaan yang tercatat sebagai anggota indeks LQ45

$\mathrm{H}_{2}$ : Net Profit Margin berpengaruh signifikan terhadap harga saham pada perusahaan yang tercatat sebagai anggota indeks LQ45.

$\mathrm{H}_{3}$ : Earning Per Share berpengaruh signifikan terhadap harga saham perusahaan yang tercatat sebagai anggota indeks LQ45.

$\mathrm{H}_{4}$ : Secara Simultan Return On Asset (ROA), Net Profit Margin (NPM), dan Earning Per Share (EPS) berpengaruh terhadap harga saham perusahaan yang tercatat sebagai anggota indeks LQ45.

\section{METODE PENELITIAN}

\section{A. Definisi Operasional}

1. Return on Asset (ROA)

Return On Assets (ROA) atau Tingkat Pengembalian Aset ini mengukur kemampuan perusahaan dalam memanfaatkan aset untuk memperoleh laba. Ratio ini mengukur tingkat pengembalian invastasi yang telah dilakukan oleh perusahaan dengan menggunakan seluruh dana (aset) yang dimiliki.

2. Net Profit Margin mengukur laba yang dihasilkan oleh setiap penjualan. Rasio ini memberi gambaran tentang laba untuk para pemegang saham sebagai persentase dari penjualan. Net Profit Margin merupakan rasio yang digunakan untuk mengukur laba bersih sesudah pajak lalu dibandingkan dengan volume penjualan.

3. Earning Per Share adalah jumlah laba yang menjadi hak untuk setiap pemegang satu lembar saham biasa. EPS hanya dihitung untuk saham biasa. Tergantung dari struktur modal perusahaan, perhitungan EPS dapat sederhana atau kompleks.

\section{B. Populasi, Sampel dan Teknik Pengambilan Sampel}

\section{Populasi}

Populasi dalam penelitian ini adalah semua kelompok perusahaan LQ45 yang terdaftar di Bursa Efek Indonesia tahun 2016-2019 berjumlah 63 perusahaan, karena setiap periode terdapat 45 perusahaan teraktif atau berbeda perusahaan. Pemilihan kelompok perusahaan LQ45 dipilih karena kelompok perusahaan LQ45 merupakan kelompok perusahaan yang mempunyai likuiditas yang tinggi dan kapitalisasi pasar yang besar serta lolos seleksi menurut beberapa kriteria pemilihan.

\section{Sampel}

Menurut Syofian (2017) merupakan metode penetapan responden untuk dijadikan sampel berdasarkan pada kriteriakriteria tertentu. Adapun kriteria sampel yang dimaksud yaitu:
a. Perusahaan yang konsisten sebagai pembentuk ndeks LQ45 selama periode 2016-2019.
b. Perusahaan perbankan tidak di perhitungkan.
c. Jumlah saham perusahaan yang beredar sebanyak lebih dari 8 miliyar lembar saham.
d. Laporan keuangan dinyatakan dalam Rupiah.

3. Teknik Pengambilan Sampel

Metode purposive sampling digunakan sebagai teknik pengambilan sampel.

\section{Jenis Dan Sumber Data}


Data yang digunakan dalam penelitian ini adalah data sekunder dimana sumber yang tidak langsung memberikan data kepada pengumpul data. Sumber data untuk penelitian ini diperoleh dari situs resmi Bursa Efek Indonesia, yaitu www.idx.co.id. Jenis data yang digunakan dalam penelitian ini adalah kualitatif dan kuantitatif.

\section{Metode Analisis Data}

Metode analisis data Menurut Sugiyono (2015) adalah proses mencari dan menyusun secara sistematis data yang diperoleh dari hasil wawancara, catatan lapangan dan dokumentasi dengan cara mengorganisasikan data ke dalam kategori, menjabarkan ke dalam unit-unit, melakukan sintesa, menyusun ke dalam pola, memilih mana yang penting dan yang akan dipelajari, dan membuat kesimpulan sehingga mudah dipahami oleh diri sendiri maupun orang lain. Berdasarkan tujuan penelitian, penelitian ini menggunakan metode analisis data dengan pendekatan kuantitatif.

\section{E. Analisis Rasio}

\section{a. Return on Asset (ROA)}

Return On Assets (ROA) atau Tingkat Pengembalian Aset ini mengukur kemampuan perusahaan dalam memanfaatkan aset untuk memperoleh laba. Ratio ini mengukur tingkat pengembalian invastasi yang telah dilakukan oleh perusahaan dengan menggunakan seluruh dana (aset) yang dimiliki. Ratio ini dapat dibandingkan dengan tingkat suku bunga bank yang berlaku. ROA ini dapat dihitung dengan cara sebagai berikut (Dwi, 2019):

$$
\text { ROA }=\frac{\text { Laba Bersih }}{\text { Total Aktiva }} \times 100 \%
$$

\section{b. Net Profit Margin (NPM)}

Net Profit Margin menurut Dwi (2019) adalah untuk mengukur rupiah laba yang dihasilkan oleh setiap rupiah penjualan. Ratio ini memberi gambaran tentang laba untuk para pemegang saham sebagai presentase dari penjualan. Net Profit Margin (NPM) dihitung dengan cara sebagai berikut :

$$
\text { Net Profit Margin }=\frac{\text { Laba Bersih Setelah Pajak }}{\text { Penjualan }} \times 100 \%
$$

\section{c. Earning per Share (EPS)}

Earning Per Share (EPS) menurut Dwi (2019) adalah jumlah laba yang menjadi hak untuk setiap pemegang satu lembar saham biasa. EPS hanya dihitung untuk saham biasa. Tergantung dari struktur modal perusahaan, perhitungan EPS dapat sederhana atau kompleks. EPS sederhana dapat dihitung dengan cara sebagai berikut:

$$
\text { EPS }=\frac{\text { Laba Bersih }}{\text { Jumlah saham yang beredar }}
$$

\section{F. Uji Asumsi Klasik}

Sebelum melakukan analisis regresi linier berganda, peneliti melakukan uji asumsi klasik yang terdiri dari uji normalitas, uji multikolinearitas, uji heterokedastisitas dan uji autokorelasi.

\section{G. Analisis Regresi Linier Berganda}

Penerapan metode regresi berganda jumlah variabel bebas (independent) yang digunakan lebih dari satu yang memengaruhi satu variabel tak bebas (dependent). Rumus dari regresi linier berganda sebagai berikut: 


$$
Y=a+b_{1} X_{1}+b_{2} X_{2}+b_{3} X_{3}+e
$$

Dimana :

$Y=$ Harga saham

$\mathrm{X}_{1}=$ Return On Asset

$\mathrm{X}_{2}=$ Net Per Share

$\mathrm{X}_{3}=$ Earning Per Share

$a=$ Konstanta

$\mathrm{b}_{1}=$ Koefisien korelasi Return On Asset

$\mathrm{b}_{2}=$ Koefisien korelasi Net Profit Margin

$\mathrm{b}_{3}=$ Koefisien korelasi Earning Per Share

$\mathrm{e}=$ Error Term

\section{H. Pengujian Hipotesis}

Pengujian ini dilakukan pada tingkat keyakinan 95\% dengan ketentuan sebagai berikut :

1) Apabila tingkat signifikansi lebih besar dari $5 \%$ maka dapat disimpulkan bahwa $\mathrm{HO}$ diterima Ha ditolak.

2) Apabila tingkat signifikansi lebih kecil dari $5 \%$ maka dapat disimpulkan bahwa $\mathrm{HO}$ ditolak dan Ha diterima

\section{HASIL DAN PEMBAHASAN}

\section{A. Analisis Rasio Keuangan}

1. Return on Asset (ROA)

ROA dapat dhitumg dari laba bersih setelah pajak dibagi dengan total aset. Berikut perhitungan ROA perusahaan

Tabel 1. Data Return on Asset

\begin{tabular}{|c|c|c|c|c|c|c|}
\hline \multirow{2}{*}{ NO } & \multirow{2}{*}{ Kode Perusahaan } & \multicolumn{4}{|c|}{ ROA (\%) } & \multirow{2}{*}{$\begin{array}{l}\text { Rata- } \\
\text { Rata }\end{array}$} \\
\hline & & 2016 & 2017 & 2018 & 2019 & \\
\hline 1 & ANTM & 0,22 & 0,45 & 5,08 & 0,64 & 1,60 \\
\hline 2 & ASII & 6,99 & 7,84 & 7,94 & 7,56 & 7,58 \\
\hline 3 & BSDE & 5,32 & 11,29 & 3,27 & 5,75 & 6,41 \\
\hline 4 & HMSP & 30,02 & 29,37 & 29,05 & 26,69 & 28,78 \\
\hline 5 & ICBP & 12,56 & 11,21 & 13,56 & 13,85 & 12,80 \\
\hline 6 & INDF & 6,41 & 5,85 & 5,14 & 6,14 & 5,88 \\
\hline 7 & KLBF & 15,44 & 14,76 & 13,76 & 12,52 & 14,12 \\
\hline 8 & MNCN & 10,41 & 10,41 & 9,83 & 13,19 & 10,96 \\
\hline 9 & $\begin{array}{l}\text { PTBA } \\
\end{array}$ & 10,90 & 20,68 & 21,19 & 15,48 & 17,06 \\
\hline 10 & SCMA & 31,40 & 24,47 & 22,38 & 15,65 & 23,47 \\
\hline 11 & TLKM & 16,24 & 16,48 & 13,08 & 12,47 & 14,57 \\
\hline 12 & WSKT & 2,95 & 4,29 & 3,71 & 0,84 & 2,95 \\
\hline 13 & WIKA & 3,86 & 2,97 & 4,53 & 6,19 & 4,39 \\
\hline
\end{tabular}

Sumber: data diolah, 2020

Berdasarkan table 1 dapat diketahui bahwa ROA yang paling tinggi pada tahun 2016 sampai dengan 2019 dimiliki oleh Unilever Indonesia Tbk. dengan kode perusahaan HMSP dengan persentase ROA berkisar antara $26,69 \%-30,02$ dengan rata-rata ROA sebesar $28,78 \%$. Artinya perusahaan sangat mampu dalam menghasilkan laba dari total aset yang dimiliki dan juga lebih besar dari rata-rata sektor industri yang sama pada tahun 2019 yaitu $4,66 \%$. Sedangkan ROA yang paling rendah pada periode empat tahun yaitu Aneka Tambang Tbk. dengan kode perusahaan ANTM dengan persentase ROA berkisar 0,22\%-5,08\% dengan rata-rata ROA sebesar 1,60\%. Artinya perusahaan 
kurang mampu dalam menghasilkan laba dari aset yang dimiliki dan juga lebih kecil dari rata-rata sektor yang sama pada tahun pada tahun 2019 yaitu sebesar 3,97\%.

\section{Net Profit Margin (NPM)}

NPM dapat dhitumg dari laba bersih setelah pajak dibagi dengan total penjualan. Tabel 2 menampilkan hasil perhitungan NPM perusahaan.

Tabel 2. Data Net Profit Margin

\begin{tabular}{|c|c|c|c|c|c|c|}
\hline \multirow{2}{*}{ No } & \multirow{2}{*}{$\begin{array}{c}\text { Kode } \\
\text { Perusahaan }\end{array}$} & \multicolumn{4}{|c|}{ NPM (\%) } & \multirow{2}{*}{$\begin{array}{l}\text { Rata- } \\
\text { Rata }\end{array}$} \\
\hline & & 2016 & 2017 & 2018 & 2019 & \\
\hline 1 & ANTM & 0,71 & 1,08 & 6,67 & 0,60 & 2,13 \\
\hline 2 & ASII & 10,11 & 11,24 & 11,44 & 11,22 & 11,00 \\
\hline 3 & BSDE & 31.24 & 49.93 & 25,67 & 44,18 & 37,76 \\
\hline 4 & HMSP & 13,37 & 12,79 & 12,68 & 12,94 & 12,95 \\
\hline 5 & ICBP & 10.54 & 9.95 & 12,13 & 12,67 & 11,32 \\
\hline 6 & INDF & 7,90 & 7,33 & 6,76 & 7.71 & 7,42 \\
\hline 7 & KLBF & 12,13 & 12,16 & 11,85 & 11,21 & 11,84 \\
\hline 8 & MNCN & 22,03 & 22,23 & 21,57 & 28,16 & 23,50 \\
\hline 9 & PTBA & 14,40 & 23,35 & 24,15 & 18,54 & 20,11 \\
\hline 10 & SCMA & 33,46 & 29,59 & 27,95 & 19,03 & 27,51 \\
\hline 11 & TLKM & 25,08 & 25,50 & 20,63 & 20,35 & 22,89 \\
\hline 12 & WSKT & 7,62 & 9,29 & 9,47 & 3,28 & 7,42 \\
\hline 13 & WIKA & 7,73 & 5,18 & 6,65 & 9,63 & 7,30 \\
\hline
\end{tabular}

Sumber: data diolah, 2020

Berdasarkan tabel 2 dapat diketahui bahwa NPM yang paling tinggi pada tahun 2016 sampai dengan 2019 dimiliki oleh Bumi Serpong Damai Tbk. dengan kode perusahaan BSDE dengan persentase berkisar antara 25,67\%49,93\% dengan rata-rata NPM sebesar 37,76\%. Artinya perusahaan sangat mampu memaksimalkan penjualan dan mengurangi beban perusahaan dan juga lebih besar dari sektor yang sama pada 2019 yaitu $-2,41 \%$. Sedangkan NPM yang paling rendah pada periode empat tahun yaitu Aneka Tambang Tbk. dengan kode perusahaan ANTM dengan persentase berkisar antara 0,60\%-6,67\% dengan rata-rata NPM sebesar 2,13\%. Artinya perusahaan kurang mampu dalam melakukan efisiensi terhadap beban perusahaan.

\section{Earning per Share (EPS)}

Earning Per Share menurut Dwi (2019) Seorang investor membeli dan mempertahankan saham suatu perusahaan dengan harapan akan memperoleh deviden atau capital gain. Laba biasanya menjadi dasar penentuan pembayaran deviden dan kenaikan nilai saham di masa datang. EPS dapat dhitumg dari laba bersih setelah bunga dan pajak dibagi dengan jumlah saham yang beredar. Tabel 3 menampilkan hasil perhitungan EPS perusahaan.

Tabel 3. Data Earning per Share

\begin{tabular}{|c|c|c|c|c|c|c|}
\hline \multirow{2}{*}{ No } & Kode & \multicolumn{4}{|c|}{ EPS (Rp) } & \multirow{2}{*}{ Rata-rata } \\
\cline { 3 - 6 } & Perusahaan & 2016 & 2017 & 2018 & 2019 & \\
\hline 1 & ANTM & 2,70 & 5,68 & 68,07 & 8,07 & 21,13 \\
\hline 2 & ASII & 452,08 & 572,20 & 657,57 & 676,12 & 589,49 \\
\hline 3 & BSDE & 107,30 & 272,09 & 89,62 & 164,84 & 158,46 \\
\hline 4 & HMSP & 109,72 & 108,93 & 116,39 & 117,97 & 113,25 \\
\hline 5 & ICBP & 311,38 & 303,82 & 399,48 & 459,61 & 368,57 \\
\hline 6 & INDF & 599,88 & 586,00 & 565,13 & 672,29 & 605,82 \\
\hline 7 & KLBF & 50,15 & 52,34 & 53,27 & 54,14 & 52,47 \\
\hline 8 & MNCN & 103,88 & 109,80 & 112,47 & 164,79 & 122,73 \\
\hline 9 & PTBA & 192,06 & 431,41 & 485,86 & 383,33 & 373,16 \\
\hline
\end{tabular}




\begin{tabular}{|c|c|c|c|c|c|c|}
\hline 10 & SCMA & 102,78 & 89,48 & 100,16 & 71,38 & 90,95 \\
\hline 11 & TLKM & 294,48 & 330,11 & 272,34 & 278,53 & 293,87 \\
\hline 12 & WSKT & 133,57 & 309,53 & 340,33 & 75,80 & 214,81 \\
\hline 13 & WIKA & 135,01 & 151,18 & 231,14 & 292,20 & 202,38 \\
\hline
\end{tabular}

Sumber: data diolah, 2020

Berdasarkan tabel 3 dapat diketahui bahwa EPS yang paling tinggi pada tahun 2016 sampai dengan 2019 dimiliki oleh Astra Internasional Indonesia Tbk. dengan kode perusahaan INDF dengan rentang nilai Rp599,88Rp672,29 dengan rata-rata EPS sebesar Rp605,82. Artinya perusahaan mampu memaksilkan panjualan perusahaan dan mampu meningkatkan laba berih sehingga dapat memberikan laba yang besar kepada para pemegang saham. Sedangkan EPS yang paling rendah pada periode empat tahun yaitu Aneka Tambang Tbk. dengan kode perusahaan ANTM dengan rentang nilai berkisar antara Rp2,70-Rp68,07 dengan rata-rata nilai Rp21,13. Artinya perusahaan kurang mampu dalam memaksimalkan laba bersih sehingga laba yang akan dibagikan kepada para pemegang saham relatif kecil.

\section{B. Statistik Deskriptif}

Statistik deskriptif digunakan untuk mengetahui tentang gambaran variabel-variabel yang ada dalam penelitian. Berdasarkan hasil analisis Desciptive Statistics menggunakan program SPSS versi 25 maka di dalam tabel 4 akan di tampilkan karakteristik sampel yang digunakan dalam penelitian ini meliputi: Jumlah Sampe (N), nilai terendah (minimun), nilai tertinggi (maximun), rata-rata sampel (mean), dan standar deviation untuk masing-masing variabel.

\section{Tabel 4. Statistik Deskriptif}

\begin{tabular}{|c|c|c|c|c|c|}
\hline & N & Min & Max & Mean & Std. Dev \\
\hline Harga Saham & 52 & 625 & 11,150 & 3634.42 & 2904.346 \\
\hline ROA & 52 & 0,22 & 31,40 & 11.4888 & 8.33125 \\
\hline NPM & 52 & 0,59 & 49,93 & 15.6263 & 10.38899 \\
\hline EPS & 52 & 2,70 & 676,12 & 246.7013 & 195.23718 \\
\hline Valid N (listwise) & 52 & & & & \\
\hline
\end{tabular}

Sumber: data diolah, 2020

Berdasarkan tabel 4 diatas menunjukkan bahwa jumlah data yang digunakan dalam penelitian ini yaitu 52 sampel. Nilai terendah (minimum) Harga Saham dari 52 sampel perusahaan adalah 625 artinya bahwa harga saham terendah selama periode penelitian yaitu Rp625 per lember saham. Nilai tertinggi (maximum) sebesar 11.150 artinya bahwa harga saham tertinggi selama periode penelitian yaitu Rp11.150 per lembar saham. Nilai rata-rata (mean) sebesar 3634,42 artinya rata-rata harga saham selama periode penelitian adalah Rp 3634,42 per lembar saham. Sedangkan standar deviasi sebesar 2904,346 artinya selama periode penelitian, ukuran penyebaran dari variabel Harga Saham adalah sebesar 2904,346 dari 52 kasus yang terjadi.

Return On Asset (ROA) mengukur kemampuan perusahaan dalam memanfaatkan aset untuk memperoleh laba. Tabel 4 menunjukkan bahwa selama periode penelitian variabel ROA memiliki nilai terendah (minimum) Return On Asset dari 52 sampel perusahaan adalah 0,22 artinya bahwa perusahaan ini mempunyai laba terendah sebesar $0,22 \%$ dari total aset yang dimiliki. Nilai tertinggi (maximum) sebesar 31,40 artinya mampu menghasilkan laba sebesar 31,40\% dari total aset yang dimiliki. Nilai rata-rata (mean) sebesar 11,4888 artinya dari 52 sampel yang diteliti selama periode waktu penelitian, rata-rata nilai keuntungan perusahaan adalah sebesar $11,4888 \%$ dari total aset yang dimiliki perusahaan. Sedangkan standar deviasi sebesar 8,33125 artinya selama periode penelitian, ukuran penyebaran dari variabel Return On asset (ROA) adalah 8,33125 dari 52 kasus yang terjadi. 
Net Profit Ma1rgin (NPM) menunjukkan kemampuan perusahaan dalam menghasilkan laba bersih dari total penjuaalan. Tabel 4 menunjukkan bahwa selama periode penelitian variabel NPM memiliki nilai terendah (minimum) sebesar 0,59 artinya bahwa kemampuan terendah perusahaan dalam menghasilkan laba bersih adalah sebesar $0,59 \%$ dari total hasil penjualan. Nilai tertinggi (maximum) sebesar 49,93 artinya perusahaan mampu menghasilkan laba bersih sebasar $49,93 \%$ dari total hasil penjualan. Nilai rata-rata (mean) sebesar 15,6263 artinya selama periode penelitian ratarata perusahaan mampu menghasilkan laba bersih sebesar 15,6263\% dari total penjualan. Sedangkan standar deviasi sebesar 10,38899 artinya selama periode penelitian ukuran penyebaran dari variabel Net Profit Margin (NPM) adalah sebesar 10,38899dari 52 kasus yang terjadi.

Earning Per Share (EPS) merupakan jumlah laba yang menjadi hak untuk setiap pemegang satu lembar saham biasa. Tabel 4 menunjukkan bahwa selama periode penelitian variabel EPS memiliki nilai terendah (minimum) 2,70 artinya bahwa keuntungan yang akan diberikan kepada pemegang saham adalah Rp2,70 per lembar saham. Nilai tertinggi (maximum) sebesar 676,12 artinya bahwa keuntungan yang akan diberikan kepada pemegang saham adalah Rp676,12 per lembar saham. Nilai rata-rata (mean) sebesar 246,7013 artinya selama periode penelitian, keuntungan yang diberikan kepada para pemegang saham adalah sebesar Rp246,7013 per lembar saham. sedangkan standar deviasi sebesar 195,23718 artinya selama periode penelitian, ukuran penyebaran dari variabel EPS adalah sebesar 195,23718 dari 52 kasus yang terjadi.

\section{Analissi Regresi Linier Berganda}

Sebelum melakukan analisis regresi berganda. Peneliti melakukan uji asumsi klasik dengan hasil bahwa uji analisis regresi linier berganda layak digunakan dalam penelitian ini. Analisis dalam penelitian ini adalah analisis regresi linier berganda. Analisis ini digunakan untuk mengetahui pengaruh dari variabel Return On Asset (ROA), Net Profit Margin (NPM) dan Earning Per Share (EPS) terhadap Harga Saham. Berdasarkan hasil perhitungan dengan menggunakan program statistik komputer SPSS for Windows Release 25 diperoleh hasil sebagai berikut :

Tabel 5. Hasil Analisis Regresi Linier Berganda

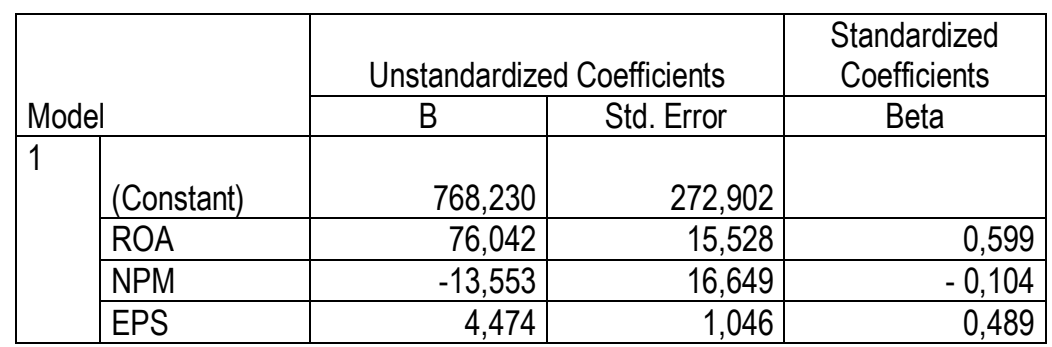

a. Dependent Variable: HARGA SAHAM

Sumber: data diolah, 2020

\section{Harga Saham $=$ 768,230 + 76,042.ROA - 13,553.NPM + 4,474.EPS+ e}

Pada persamaan di atas ditunjukkan pengaruh variabel Return On Asset (ROA), Net Profit Margin (NPM) dan Earning Per Share (EPS) terhadap variabel dependen Harga Saham. Adapun arti dari koefisien regresi tersebut adalah: 1. Nilai Konstanta atau a $=768,230$, artinya bahwa jika tidak ada variabel bebas yang terdiri dari Return On Asset (ROA), Net Profit Margin (NPM) dan Earning Per Share (EPS) yang mempengaruhi Harga Saham, maka besarnya Harga saham akan sebesar 768,230.

2. Koefisiensi regresi Return On Asset (ROA) atau $\beta_{1}=76,042$, artinya setiap kenaikan Return On Asset (ROA) sebesar 1 persen, maka Harga Saham akan meningkat sebesar 76,042 dengan asumsi bahwa variabel independen lain dalam kondisi konstan. Hasil ini berarti bahwa antara Return On Asset (ROA) dan Harga Saham menunjukkan hubungan 
yang searah. Return On Asset (ROA) yang semakin meningkat mengakibatkan peningkatan Harga Saham, begitu pula sebaliknya jika Return On Asset (ROA) semakin menurun mengakibatkan penurunan Harga Saham.

3. Koefisiensi regresi Net Profit Margin atau $\beta_{2}=-13,553$, artinya setiap kenaikan Net Profit Margin (NPM) sebesar 1 persen, maka Harga Saham akan menurun sebesar 13,553 dengan asumsi bahwa variabel independen lain dalam kondisi konstan. Hasil ini berarti bahwa antara Net Profit Margin (NPM) dan Harga Saham menunjukkan hubungan yang berlawanan. Net Profit Margin (NPM) yang semakin meningkat mengakibatkan Harga Saham turun, begitu pula sebaliknya jika Net Profit Margin (NPM) yang semakin menurun mengakibatkan Harga Saham meningkat.

4. Koefisien regresi Earning Per Share atau $\beta_{3}=4,474$, artinya setiap kenaikan Earning Per Share (EPS) sebesar 1 persen, maka Harga Saham akan meningkat sebesar 4,474 dengan asumsi variabel independen lain dalam kondisi konstan. Hasil ini berarti bahwa Earning Per Share (EPS) dan Harga Saham menunjukkan hubungan yang searah. Earning Per Share (EPS) yang semakin meningkat mengakibatkan peningkatan Harga Saham, begitu pula sebaliknya jika Earning Per Share (EPS) yang semakin menurun maka mengakibatkan penurunun Harga Saham.

\section{Pengujian Hipotesis}

\section{Uji t}

Berdasarkan hasil perhitungan dengan menggunakan program statistik komputer SPSS for Windows Release 25 dapat dilihat pada tabel 6.

\begin{tabular}{|c|c|c|c|c|c|c|}
\hline \multirow{2}{*}{\multicolumn{2}{|c|}{ Model }} & \multicolumn{2}{|c|}{ Unstandardized Coefficients } & \multirow{2}{*}{$\begin{array}{c}\text { Standardized } \\
\text { Coefficients } \\
\text { Beta }\end{array}$} & \multirow[b]{2}{*}{$t$} & \multirow[b]{2}{*}{ Sig. } \\
\hline & & $\mathrm{B}$ & Std. Error & & & \\
\hline \multirow[t]{4}{*}{1} & (Constant) & 768,230 & 272,902 & & 2,815 & 0,008 \\
\hline & ROA & 76,042 & 15,528 & 0,599 & 4,897 & 0,000 \\
\hline & NPM & $-13,553$ & 16,649 & $-0,104$ & $-0,814$ & 0,421 \\
\hline & EPS & 4,474 & 1,046 & 0,489 & 4,276 & 0,000 \\
\hline
\end{tabular}

Sumber:data diolah, 2020

Penjelasan hasil uji t masing-masing variabel bebas adalah sebagai berikut :

a. Nilai koefisien Return On Asset (ROA) sebesar 76,042 yang berarti bahwa Return On Asset (ROA) menunjukkan hubungan positif terhadap Harga Saham. Nilai signifikansi sebesar 0,000 lebih kecil dari tingkat signifikasi $a=$ 5\%. Menunjukkan bahwa Return On Asset (ROA) berpengaruh positif signifikan terhadap Harga Saham.

Return On Asset menurut Tandelilin (2018) menyatakan bahwa Return On Asset menggambarkan sejauh mana kemampuan asset-aset yang dimiliki perusahaan bisa menghasilkan laba. Semakin tinggi rasio ROA menunjukkan bahwa perusahaan semakin efektif dalam memanfaatkan aktiva untuk menghasilkan laba bersih, yang juga dapat diartikan bahwa kinerja perusahaan semakin efektif. Hal ini selanjutnya akan meningkatkan daya tarik perusahaan kepada investor dan juga akan berdampak kepada harga saham dari perusahaan tersebut di pasar modal, dengan kata lain ROA akan berpengaruh terhadap harga saham perusahaan. Dari hasil penelitian diatas berarti Return On Asset berpengaruh positif terhadap harga saham sudah sesuai dengan hipotesis yang telah peneliti uraikan sebelumnya. Hubungan antara Return On Asset dengan harga saham adalah berpengaruh positif dan signifikan yang berarti bahwa Return On Asset dapat menaikan harga saham. Return On Asset diperoleh dari laba setelah pajak dan total aktiva, jika laba setelah pajak naik dan total aktiva tetap dapat menunjukkan bahwa kondisi keuangan bagus, maka dapat membuat daya tarik investor untuk menanamkan 
uangnya. Dengan banyaknya investor yang menanamkan uangnya atau daya beli bertambah berarti menunjukkan suatu sinyal bahwa harga saham akan naik. Hasil penelitian ini sesuai dengan penelitian yang dilakukan Siti (2018) yang membuktikan bahwa Return On Asset (ROA) mempunyai pengaruh yang signifikan terhadap harga saham. Demikian pula dalam penelitian yang dilakukan oleh Nike, Nurhajati dan Budi (2019) membuktikan bahwa ROA berpengaruh signifikan terhadap harga saham. Sama halnya dengan penelitian yang dilakukan oleh Jalil (2020) yang membuktikan bahwa variabel ROA berpengaruh signifikan terhadap Harga Saham.

b. Nilai koefisien Net Profit Margin (NPM) sebesar -13,553 yang berarti bahwa Net Profit Margin (NPM) menunjukkan hubungan negatif terhadap Harga Saham. Nilai signifikasi sebesar 0,421 lebih besar dari tingkat signifikasi $a=$ 5\%. Menunjukkan bahwa Net Profit Margin (NPM) tidak berpengaruh signifikan terhadap Harga Saham.

Maka dalam hal ini terjadi inkonsistensi dengan teori dari Net Profit Margin yang memiliki pengertian untuk mengukur profitabilitas yang berkaitan dengan penjualan yang dihasilkan, penghasilan bersih penjualan, NPM atau margin laba bersih merupakan keuntungan penjualan setelah menghitung seluruh biaya dan pajak penghasilan. Net Profit Margin memperlihatkan rasio-rasio finansial perusahaan, apabila rasio profitabilitas semakin besar berarti semakin bagus perusahaan dalam menghasilkan laba (Tandelilin, 2017). Net Profit Margin didapat dari penjualan atau pendapatan dan laba bersih perusahaan. Net Profit Margin memiliki pengaruh yang negatif di dalam penelitian ini. Hal ini dapat diakibatkan oleh unsur dasar dari Net Profit Margin itu sendiri, dimana investor biasanya akan lebih memperhatikan angka penjualan bersih atau omzet dari peusahaan pada saat akan mengambil keputusan untuk berinvestasi. Meningkatnya penjualan yang tidak diikuti meningkatnya laba bersih dapat menurunkan persentasi Net Profit Margin. Tidak berpengaruhnya variabel ini disebabkan karena kemampuan perusahaan dalam mendapatkan laba melalui penjualan dianggap cukup rendah. Kenaikan penjualan tapi tidak diikuti oleh kenaikan laba bersih. Selain itu, kemampuan perusahaan dalam menekan pengeluaran biaya-biaya yang dilakukan perusahaan kurang efisien sehingga akan mengurangi kepercayaan investor untuk menanamkan modalnya pada perusahaan tersebut. Hasil penelitian ini sesuai dengan penelitian yang dilakukan oleh Nike, Nurhajati dan Budi (2019) yang membuktikan bahwa Net Profit Margin (NPM) tidak berpengaruh signifikan terhadap harga saham. Serta Sindi, Ronny dan Budi (2020) yang membuktikan variabel NPM tidak mempunyai pengaruh yang signifikan terhadap Harga Saham.

c. Nilai koefisien Earning Per Share (EPS) sebesar 4,474 yang berarti bahwa Earning Per Share (EPS) menunjukkan hubungan positif terhadap Harga Saham. Nilai signifikansi 0,000 lebih kecil dari $a=5 \%$. Menunjukkan bahwa Earning Per Share (EPS) berpengaruh positif dan signifikan terhadap Harga Saham.

Earning Per Share adalah jumlah laba yang menjadi hak untuk setiap pemegang satu lembar saham biasa. EPS hanya dihitung untuk saham biasa. Tergantung dari struktur modal perusahaan, perhitungan EPS dapat sederhana atau kompleks (Dwi, 2019). Hal ini menunjukkan bahwa informasi Earning Per Share yang terdapat dalam laporan keuangan merupakan hal yang penting dalam membuat keputusan investasi. Hubungan antara Earning Per Share dengan harga saham adalah berpengaruh positif dan signifikan yang berarti bahwa Earning Per Share dapat menaikan harga saham. EPS terdiri dari laba bersih perusahaan dikurangi dengan deviden dan dibagi dengan jumlah saham yang beredar. Semakin tinggi nilai EPS menunjukkan bahwa perusahaan semakin efektif dalam menghasilkan laba bersih. Hal ini selanjutnya akan meningkatkan daya tarik perusahaaan kepada investor dan juga akan berdampak kepada harga saham dari perusahaan tersebut di pasar modal. Dengan banyaknya investor yang menanamkan uangnya atau daya beli bertambah berarti menunjukkan suatu sinyal bahwa harga saham akan naik. Hasil penelitian ini sesuai dengan penelitian yang dilakukan oleh Calista (2019) yang membuktikan bahwa Earning Per Share (EPS) berpengaruh signifikan terhadap harga saham. Serta penelitian yang dilakukan oleh Indah dan Zulfa (2019) membuktikan bahwa EPS memiliki pengaruh yang signifikan terhadap harga saham. Sama halnya dengan penelitian yang dilakukan oleh Ahmad dan Anava (2020) yang membuktikan bahwa variabel EPS berpengaruh signifikan terhadap Harga Saham.

\section{Uji F}


Uji F adalah uji simultan yang digunakan untuk mengetahui pengaruh variabel Return On Asset (ROA), Net Profit Margin (NPM) dan Earning Per Share (EPS) terhadap Harga Saham secara simultan atau bersama-sama. Berdasarkan hasil perhitungan dengan menggunakan program statistik komputer SPSS for Windows Release 25 diperoleh hasil sebagai berikut:

Tabel 7. Hasil Uji F

\begin{tabular}{|c|c|c|c|c|c|c|}
\hline \multicolumn{2}{|c|}{ Model } & Sum of Squares & $\mathrm{df}$ & Mean Square & $\mathrm{F}$ & Sig. \\
\hline \multirow[t]{3}{*}{1} & Regression & 28809154,701 & 3 & 9603051,567 & 17,708 & $0,000^{\mathrm{b}}$ \\
\hline & Residual & 17895768,272 & 33 & 542296,008 & & \\
\hline & Total & 46704922,973 & 36 & & & \\
\hline \multicolumn{7}{|c|}{ a. Dependent Variable: HARGA SAHAM } \\
\hline
\end{tabular}

Sumber: data diolah, 2020

Berdasarkan dari hasil perhitungan yang ditunjukkan pada tabel $4.15 \mathrm{di}$ atas, diperoleh nilai signifikansi sebesar 0,000 . Pada tingkat signifikansi $a=5 \%$. Nilai signifikansi $0,000<0,05$, maka dapat disimpulkan bahwa ada pengaruh secara simultan atau bersama-sama antara variabel Return On Asset (ROA), Net Profit Margin (NPM) dan Earning Per Share (EPS) terhadap Harga Saham.

Return On Asset (ROA), Net Profit Margin (NPM) dan Earning Per Share (EPS) merupakan faktor yang termasuk kedalam rasio profitabilitas. Maka dari itu jika kombinasi Return On Asset, Net Profit Margin dan Earning Per Share tinggi secara bersama-sama akan memberikan pengaruh positif yang besar terhadap harga saham. Return On Asset diperoleh dari laba bersih dibagi total aktiva. Net Profit Margin didapat dari laba bersih dibagi penjualan serta Earning Per Share diperoleh dari laba bersih dikurang deviden dan dibagi dengan jumlah saham yang beredar. Jika penjualan dan laba bersih meningkat sedangkan total aktiva, deviden dan jumlah saham yang beredar tetap sama maka ROA, NPM dan EPS akan meningkat dan menunjukkan bahwa kondisi keuangan bagus. Dengan kondisi keuangan yang bagus maka dapat membuat daya tarik investor yang kuat untuk menanamkan uangnya. Dengan demikian semakin banyak investor yang menanamkan uangnya atau daya beli bertambah menunjukkan suatu sinyal bahwa harga saham akan naik. Hasil penelitian ini konsisten dengan penilitian yang dilakukan oleh Nike, Nurhajati dan Budi (2019) bahwa ROA, NPM dan EPS secara simultan berpengaruh signifikan terhadap harga saham.

\section{PENUTUP}

\section{A. Simpulan}

Beberapa kesimpulan dari penelitian ini dapat dijelaskan sebagai berikut:

1. Variabel Return On Asset (ROA) dalam penelitian ini berpengaruh signfikan terhadap harga saham. Semakin besar laba yang diperoleh berdasarkan aset yang dimiliki maka akan berdampak terhadap kenaikan harga saham perusahaan.

2. Variabel Net Profit Margin (NPM) tidak berpengaruh signifikan terhadap harga saham sehingga kemampuan perusahaan untuk mendapatkan laba juga rendah. Keputusan yang harus diambil oleh pemilik yaitu perusahaan harus meningkatkan penjualan dan menekan biaya beban agar perusahaan menghasilkan laba yang tinggi karena semakin besar NPM maka kinerja perusahaan akan semakin produktif, sehingga akan meningkatkan kepercayaan investor untuk menanamkan modalnya dalam perusahaan

3. Variabel Earning Per Share (EPS) dalam penelitian ini berpengaruh signifikan terhadap harga saham. EPS diukur berdasarkan laba bersih dibagi dengan jumlah saham beredar. Apabila jumlah EPS perusahaan meningkat akan mengakibatkan harga saham meningkat. 
4. Berdasarkan dari hasil perhitungan ynng telah dilakukan bahwa Return On Asset (ROA), Net Profit Margin (NPM), dan Earning Per Share (EPS) berpengaruh siginifikan terhadap Harga Saham. Semakin besar nilai ROA, NPM dan EPS akan berdampak terhadap kenaikan harga saham.

\section{B. Saran}

Berdasarkan kesimpulan di atas, maka penulis memberikan saran dalam penelitian ini antara lain:

1. Penelitian selanjutnya dapat mengembangkan jumlah variabel yang akan diteliti dan memperluas sampel perusahaan,

2. Periode penelitian yang digunakan ditambah sehingga menghasilkan informasi yang lebih mendukung.

\section{DAFTAR PUSTAKA}

Ahmad Ulil Albab AL Umar dan Anava Salsa Nur Savitri. 2020. Pengaruh ROA, ROE, EPS Terhadap Harga Saham. Jurnal Analisa Akuntansi dan Perpajakan. Vol. 4. No. 1.

Calista F. Arianto. 2019. Pengaruh ROA, ROE, EPS, Dan NPM Terhadap Harga Saham Perusahaan Asuransi. Jurnal IImu dan Riset Manajemen. Vol. 8. No. 8.

Dewi K. Dian, Adiputra I Made, Yuniarta Gede. 2015. Pengaruh Deviden Per Share Dan Earning Per Share Terhadap Harga Saham Pada Perusahaan Manufaktur yang Go Public yang Terdaftar di Bursa Efek Indonesia Periode 2009-2013. Jurusan Akuntansi Program S1, Fakultas Ekonomi dan Bisnis, Universitas Pendidikanf.

Dwi, Prastowo. 2019. Analisis Laporan Kenuangan Konsep dan Aplikasi. Yogyakarta:UPP STIM YKPN.

Fahmi, I. 2017. Analisis Laporan Keuangan. Edisi Keenam. Bandung: CV ALFABETA.

Gerald Edsel Yermia Egam, Ventje llat dan Sonny Pangerapan. 2017. Pengaruh Return On Asset (ROA), Return On Equity (ROE), Net Profit Margin (NPM) dan Earning Per Share (EPS) Terhadap Harga Saham

Hanafi, Mahmud. 2016. Manajemen Keuangan. Edisi Pertama. Penerbit BPFE-Yogyakarta.

Hery. 2015. Analisis Laporan Keuangan. CAPS (Center for Academic Publishing Service). Yogyakarta.

Indra Saputra, Veny \& Sekar Mayangsari. 2018. Pengaruh Rasio Keuangan, Aksi Korporasi Dan Faktor Fundamental Ekonomi Makro Terhadap Harga Saham. Jurnal Magister Akuntansi Trisakti. Vol. 5 No. 1.

Jalil, Muhammad, 2020. Pengaruh EPS, ROA, DER dan CR Terhadap Harga Saham Pada Perusahaan Makanan Dan Minuman Yang Terdaftar Di Bei Periode 2015-2017. Jurnal Akuntansi dan Keuangan. Vol. 9. No. 1

Nike L. Dwi Putri, Nurhajati dan Budi Wahono. 2019. Pengaruh Return On Assets (ROA), Net Profit Margin (NPM), Dan Earning Per Share (EPS), Terhadap Harga Saham (Studi Kasus Pada Perusahaan Manufaktur Yang Terdaftar Di Bursa Efek Indonesia Periode 2014-2018). Jurnal Riset Manajemen. Unisma

Prayogi. 2020. Pengaruh Rasio Struktur Permodalan Dan Rasio Profitabilitas Terhadap Harga Saham Perusahaan Batu Bara Yang Tercatat Di Bursa Efek Indonesia. Skripsi. Universitas Pertamina.

Putri, Yuanda Romadhan dan Budhi Satrio. 2019. Pengaruh ROA, ROE, NPM dan EPS Terhadap Harga Saham Lq45 Di Bursa Efek Indonesia. Jurnal Ilmu dan Riset Manajemen. Vol. 8, No 6. 
Rosdian Widiawati Watung dan Ventje llat, 2016. Pengaruh Return On Asset (ROA), Net Profit Margin (NPM) Dan Earning Per Share (EPS) Terhadap Harga Saham Perusahaan Perbankan Di Bursa Efek Indonesia Periode 2011-2015. Jurnal EMBA, Vol. 4, No. 2.

Ryan, Filbert. 2018. Investasi Saham Ala Swing Trader Dunia. Elex Media Komputindo: Jakarta.

Ryan, Filbert. 2018. Trading Vs Investing. Elex Media Komputindo:Jakarta

Safiah, S., \& Kuddy, A. L. L. (2021). Pengaruh Profitabilitas Terhadap Nilai Perusahaan Dengan Kebijakan Dividen Sebagai Variabel Intervening. JUMABIS (Jurnal Manajemen dan Bisnis), 5(1), 1-13.

Siti, Khoiriyah. 2018. Pengaruh Return On Asset (Roa), Return On Equity (Roe), Net Profit Margin (Npm), Dan Earning Per Share (Eps) Terhadap Harga Saham Pada Perusahaan Yang Tergabung Dalam Indeks Lq45 Yang Terdaftar Di Bursa Efek Indonesia Periode 2013-2016. simki.unpkediri.ac.id

Sugiyono. 2015. Metode Penelitian Kombinasi (Mix Methods). Bandung: Alfabeta.

Syofian, Siregar. 2017. Metode Penelitian Kuantitatif. Cetakan Keempat. Jakarta: Kencana

Weygandt, Jerry J.; Kimmel, Paul D., dan Keiso, Donald E. (2015), Accounting Principle 12th Edition. United States of America, John Wiley and Sons. 